\title{
HRG Gene
}

National Cancer Institute

\section{Source}

National Cancer Institute. HRG Gene. NCI Thesaurus. Code C88167.

This gene may be involved in coagulation and ion fixation. 